\title{
The intention of households in the Daklak province to instal smart grid rooftop solar electricity systems
}

Tran Thi Lan ${ }^{1,2}$, Sopin Jirakiattikul ${ }^{3}$, Le Duc Niem² and Kuaanan Techato ${ }^{1,4^{*}}$ (i)

\begin{abstract}
Background: Smart grid rooftop solar electricity is a useful power resource and a viable alternative to conventionally generated energy. In the context of Vietnam, it could help people control their own source of electrical power and reduce power outages. This problem is expected to worsen in the future. Previous studies have shown that very few smart grid rooftop solar electricity systems have been installed by households in the Daklak Province, in the Central Highlands of Vietnam, and that as of 30th May 2019, only 18 out of 435,688 households had installed such a system. Moreover, only a small number of people knew about this resource.

Method: Based on previous investigations, this study proposed a research model that includes factors, which might affect the intention to instal smart grid rooftop solar electricity systems. However, the amount of money that people would be willing to pay (WTP) for the installation of such systems depends on their current electricity consumption. Therefore, to investigate this issue, a questionnaire was developed to survey 300 households in the Daklak Province, in the Central Highlands of Vietnam. A probit binary model was used to analyse the collected data from the questionnaire for this study.
\end{abstract}

Results: After interviewing the respondents from the 300 households in the research area and introducing into the concept and benefits of the smart grid solar electricity generating systems, they were more aware and knowledgeable of the concept. Thirty-three percent of households mentioned that they intended to instal such a system and were willing to pay between USD 1240 and USD 2220 for an appropriate-sized system based on their current electricity consumption and needs. Those households that possessed a high awareness of smart grid rooftop solar power were more likely to express the intention to instal such a system. However, it was also revealed that government incentives and household attitudes were important factors that influence the intention to instal such a system. In contrast, factors such as environmental concerns and the innovativeness of households were less influential.

Conclusion: The awareness and understanding of the 309 households surveyed in this study regarding smart grid rooftop solar electricity systems and government incentives were the leading factors that affected the people's intention to instal such systems. The majority of the respondents were willing to pay between USD 1240 and USD 2220 for installing such a system. In progressing this initiative in Vietnam, based on the results of this study, the Vietnamese government could identify those households that have the necessary degree of knowledge and awareness of such systems and offering incentives to instal such systems. The government could also develop communication

*Correspondence: kuaanan.t@psu.ac.th

${ }^{1}$ Faculty of Environmental Management, Prince of Songkla University, Hat

Yai, Songkhla 90112, Thailand

Full list of author information is available at the end of the article original author(s) and the source, provide a link to the Creative Commons licence, and indicate if changes were made. The images or other third party material in this article are included in the article's Creative Commons licence, unless indicated otherwise in a credit line to the material. If material is not included in the article's Creative Commons licence and your intended use is not permitted by statutory regulation or exceeds the permitted use, you will need to obtain permission directly from the copyright holder. To view a copy of this licence, visit http://creativecommons.org/licenses/by/4.0/. The Creative Commons Public Domain Dedication waiver (http://creativeco mmons.org/publicdomain/zero/1.0/) applies to the data made available in this article, unless otherwise stated in a credit line to the data. 
programmes and other initiatives to enhance the understanding and awareness of the community of rooftop solar electricity so that programmes for the development of alternative energy sources could be more effective.

Keywords: Household, Intention, Central Highlands, Rooftop solar, Smart grid, Vietnam

\section{Background}

Most energy consumed globally is generated from conventional resources. According to the International Energy Agency (IEA), 81\% of the total primary energy consumption globally in 2017 was derived from fossil fuels $[1,2]$. However, there are many drawbacks to using fossil fuels, since the generation of emissions from the combustion of these fuels has adverse effects on climate change, global warming [3], and humanity [4]. Moreover, increasing energy consumption will ultimately lead to exhausting conventional resources in the future [5]. According to Shafiee and Topal [6], in approximately 35 years from 2005, natural oil supplies will be completely depleted, while natural gas and coal stocks will be exhausted in 37 years to a 107 years' time, respectively. As a result, coal will potentially be the only fossil fuel resource still existing after 2042, and it, too, will be depleted in 2112 based on current and future energy demands [6]. Therefore, research relating to these drawbacks and limitations, afforded to energy derived from fossil fuels, has attracted the attention and interest of many scientists to investigate renewable energy resources in many countries worldwide [7].

As the overall situation relating to the generation and consumption of electricity in Vietnam is unstable, and based on current projections, it is expected that power cuts will occur regularly from 2020, especially during the hot season [8]. Coal, gas and hydropower resources account for over $90 \%$ of the electricity generated in Vietnam, with $35 \%$ of total power production based on hydropower [9-11]. However, hydropower dams give rise to certain problems for the environment and society. For instance, in areas where dams are constructed, local communities must be aware [12-14] that the local ecosystem is threatened, and the environment harmed. In contrast, dams also bring several advantages, such as the generation of power, land irrigation and control of flooding [15-17]. In Vietnam, more than 200,000 people have been relocated due to the construction of hydropower dams, which involved the destruction of 44,557 homes and the loss of 133,930 hectares of land [18]. Moreover, the volume of river discharge and the capacity for power generation may decline due to deforestation in constructing hydropower dams [19].

Wind power, biomass energy and solar power are all sustainable sources of energy, the use of which is supported by the Vietnamese government through feed-in tariffs (FITs), whereby consumers can sell the electricity they generate to the electricity grid. Solar power particularly, is seen as a suitable source in generating electricity in the Central Highlands and the southern area of Vietnam [20]. The Central Highlands have a high potential for the generation of solar energy since it has an annual 'sunshine' duration of between 2000 and $2600 \mathrm{~h} \mathrm{[21].} \mathrm{After} \mathrm{evaluating} \mathrm{the} \mathrm{solar} \mathrm{radia-}$ tion at 171 sites in Vietnam, Polo et al. [20] showed that the Central Highlands and South Vietnam, with the highest potential concentration of solar energy, had the capacity to generate an average of about $5.6 \mathrm{kWh} / \mathrm{m}^{2}$ of electricity per day. Daklak Province has an available rooftop space of $22.4 \mathrm{~km}^{2}$ for the installation of the system [22]. The Vietnamese government is also seeking to promote the installation of rooftop solar electricity generation systems at the second-highest FIT price for electricity that is generated directly from the burning of biomass [23-26].

Smart grid rooftop solar electricity systems offer further benefits compared to off-grid and hybrid solar systems given they are cheaper to instal and do not require a battery, which needs to be replaced every 2 to 5 years. Smart grid systems are also appropriate for installation in the Central Highlands since more than $95 \%$ of houses and other dwellings in this region are currently connected to the electricity grid [27].

There are five provinces in the Central Highlands of Vietnam, namely, Kontum, Gialai, Daklak, Daknong, and Lamdong, where Daklak is optimally located in the middle of the Central Highlands and regarded as the metropolis of the area [28]. This province also has the highest population in the region, with $1,919,147$ people and 435,688 households, and the total duration of sunshine in 2018 was 2431.30 h [29]. However, even though rooftop solar electricity systems are available in the province, as at the 30th May 2019, only 18 from the 435,688 households had installed such systems, and almost all are smart grid systems [30]. It was therefore interesting to investigate why the number of people who had installed smart grid rooftop solar systems was so low and what are, the factors affecting the intention of people to instal such systems, and what percentage were willing to pay for installing instal the system. Accordingly, this study focused on these three issues. 


\section{Literature review}

\section{Definition of a smart grid}

A smart grid (SG) is defined as a smart electricity/power grid, a future grid, a mobile grid, or an internal grid that is an evolution of the twentieth-century electrical grid. Conventional power grids are typically used to distribute power from a few central generators to a vast number of users. In contrast, a smart grid uses two-way electricity and information to create an integrated and distributed advanced electricity supply network [31].

In Vietnam, SG development was adopted by the Government in 2012 through Decision 1670/QD-TTg of October 2012, which encourages investments in renewable energy and SGs. SGs have two-way power, where customers can sell the surplus power from their renewable energy supply to the grid and buy electricity from the grid [32].

\section{SG rooftop solar electricity systems}

SG PVs can be mounted on the rooftops of buildings, offices or other commercial and industrial buildings. In comparison to other forms of solar energy, an SG rooftop PV offers a two-way exchange, where electricity can be directly targeted either from a power utility to consumers or in the opposite direction when the consumers' systems generate more power than they consume. As such, an SG rooftop PV can help the PV system to run smoothly and in a stable manner in the following ways [33]:

- If the customer's need is >than the capacity generated by the system, the inverter will withdraw the power required from the grid;

- If the customer's need is = to the capacity generated by the system, the power generated from the rooftop solar electricity system will be used to meet the customer's requirements;

- If the customer's need is < than the capacity generated by the system, the surplus electricity will be sent to the grid.

The process of determining the relationship between the generation of electricity and the need of consumers' and controlling or regulating the flow of power occurs continuously and automatically, without the need for user intervention.

In Vietnam, the surplus energy acquired from domestic solar power systems and the power available from the grid has been determined by two-way meters from 1st July 2019, based on Decision No. 02/2019/QD-TTg. Nevertheless, consumers can sell power to EVN at an FIT price of USD 9.35/1kWh independent of the power they purchase from the grid [26].

Smart grid rooftop solar systems are highly suitable for the Central Highlands as $95.17 \%$ of households in this region are currently connected to the electricity grid [27]. The benefits of SG rooftop PVs are lower installation costs and the fact that consumers will not need to replace the batteries every 2 to 5 years. In addition, unused electricity from the system can be sold to EVN at a reasonable price.

\section{Methodology \\ Study area}

As mentioned earlier, the Central Highlands of Vietnam have a high potential for solar energy, and almost all households in the area are currently connected to the electricity grid. Therefore, it is a suitable region for the installation of smart grid rooftop solar electricity systems. Daklak Province comprises a city, named Buon Ma Thuot, a town, and 13 districts. This study was conducted in Eatam Ward in Buon Ma Thuot City (see Fig. 1). This ward is close to the centre of Buon Ma Thuot and has 1,154 households [29]. The economy of Eatam is reasonably well developed, having a large university; the Tay Nguyen University.

\section{Sample size and data collection}

The target population for this research comprised 1154 households in Eatam Ward [29]. The sample was calculated based on the following formula [34]:

$$
n=\frac{N}{1+N e^{2}},
$$

where $n$ is the size of the sample, $N$ is the size of the population, and $e$ is the sampling error $( \pm 5 \%)$. Thus, the sample was determined as:

$$
n=\frac{1,154}{1+1,154 \times 0.05^{2}}=297.03 .
$$

Furthermore, the sample size adopted was 300 households.

A draft questionnaire was developed based on a review of previous studies, with the selected items appropriately adjusted to the Vietnamese situation. The questionnaire 


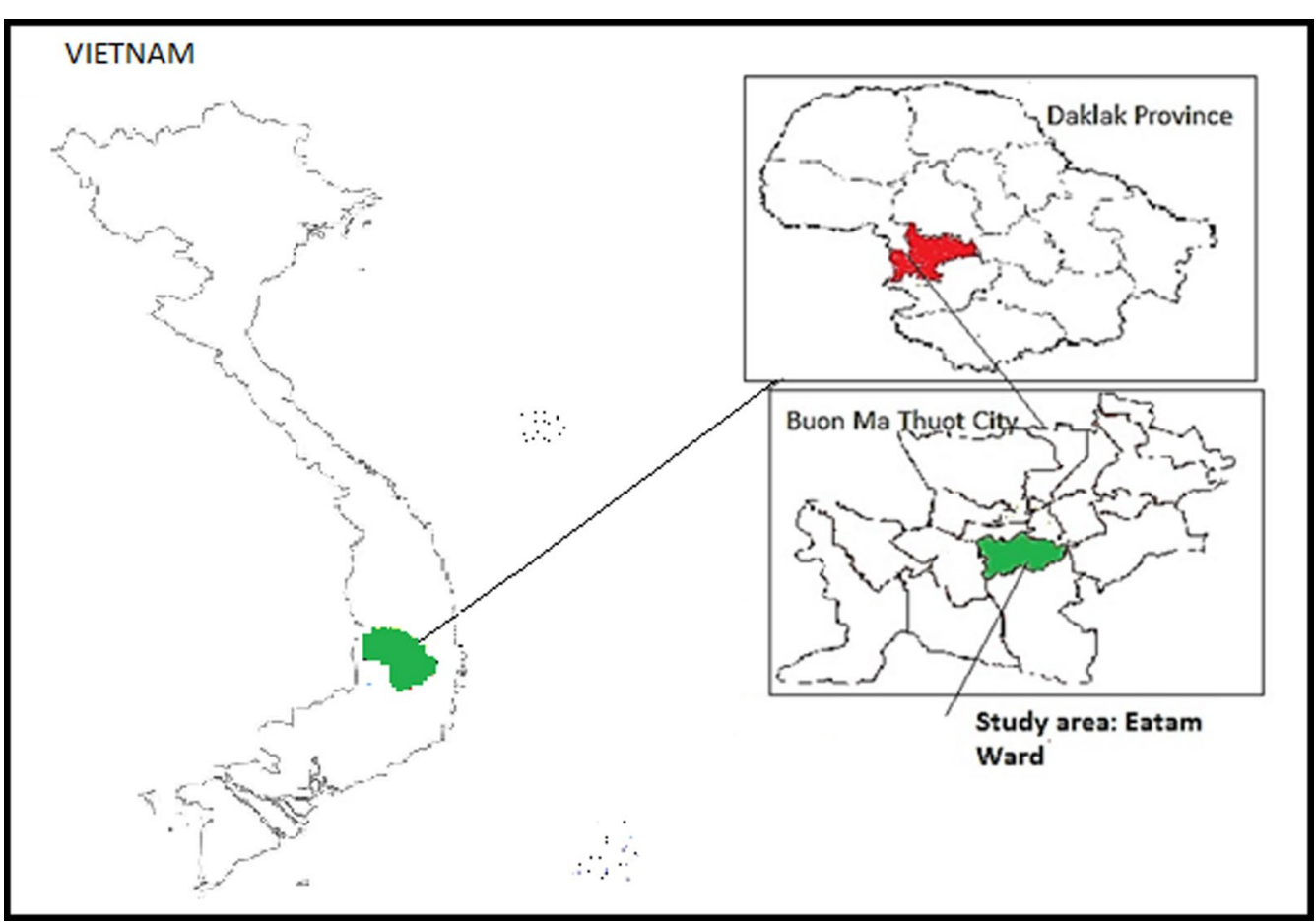

Fig. 1 The study area (source: https://daklak.gov.vn/web/english)

(refer to Appendix 1) commenced with an introduction about smart grid rooftop solar energy systems, after which, the items that constituted the main part of the questionnaire were addressed to the respondents. A presurvey was conducted before the main study to ensure that all the items in the questionnaire were capable of being understood by the respondents in the main survey. After the pre-survey, the main survey was conducted in the research area between May and July 2019 with the 300 households purposively selected by convenience sampling. The survey investigated the intention of the participating households to instal rooftop solar systems in the future. Only those households that had not installed smart grid rooftop solar electricity systems participated in the survey. The sample was selected so that only those households whose dwellings had a rooftop deemed appropriate for the installation of a rooftop solar power system were included. The questionnaire consisted of two parts. Part 1 contained questions relating to the factors that affected their intention to instal a rooftop solar power system, while Part 2 collected information relating to the demographics of the households.

In Vietnam, unmarried people often live with their parents and are unable to make their own personal decisions. They also do not have their own house, so the installation of solar systems is not possible. Therefore, only households that comprised a married couple and their relatives were included in the survey. In some families, the husband answered the survey items, while in others, the items were answered by the wife. The items were all addressed to the participants in the local language, Vietnamese, by the researchers, who recorded the respondents' answers.

\section{Data analysis}

The research model was designed according to previous research. Customers mostly purchase electricity based on the payment of a monthly bill rendered in arrears for the actual amount of electricity consumed during the preceding period. However, installing a rooftop solar power system involves a substantial, long-term financial commitment, and there are uncertainties associated with the payback period and future utility costs as well as the likelihood of improvements occurring in rooftop solar technologies. Ek found in 2005 that individuals who show a positive attitude towards wind power pay more attention to the unfavourable consequences of environmental problems to humans and the ecosystem resulting from 
conventional electricity generation, and are probably, therefore, more focused on collective or altruistic values [35]. Attitudes are composed of views and opinions toward objects that vary in specificities [36]. Therefore, people may have beliefs and may care or be concerned about specific problems such as the effects of fossil fuels on climate change and global warming. Consequently, this may lead them to adopt certain behaviours, as posited in the theory of planned behaviour [37]. According to Roberts, consumers will opt for environmentally friendly products if they have good knowledge of such products or the contribution of the products to the health of the environment or of other individuals [38]. Faiers and Neame meanwhile, suggested that consumers may be uncertain and confused if they do not have sufficient knowledge about products [39]. Previous empirical research has concluded that environmental concerns and values, and the innovativeness of consumers will have an impact on people's intention to instal solar electricity systems [40-42]. Government incentives have also been found to have a strong influence on such intentions [42].

Based on the theory of planned behaviour (TPB), the intention of households to instal smart grid rooftop solar electricity systems would be influenced by their awareness of rooftop solar electricity generation and other environmental concerns, the innovativeness and attitudes of the households, and the incentives being offered by the government to instal such systems, as illustrated in Fig. 2.

A probit binary model was used in this research to analyse the factors that affect the intention of households to instal smart grid rooftop solar systems, as illustrated in Eq. 1 below:

$$
\boldsymbol{Y}=\beta x+\varepsilon,
$$

where $\boldsymbol{Y}$ is the dependent variable: intention to instal smart grid rooftop solar system, $\boldsymbol{\beta}$ is the coefficient valuation, and $\boldsymbol{x}$, independent variables: awareness about rooftop solar electricity, environmental concerns, innovativeness, attitudes, government incentives. The independent variables were measured using items employed in earlier studies (see Table 1) [41-43].

In this research, the dependent variable for each household $(Y i)$ was assessed as a binary variable as follows:

$Y i=0$ : the household does not intend to instal a rooftop solar electricity system;

$Y i=1$ : the household intends to instal a rooftop solar electricity system; where Yi is the intention to instal of family i

Since $Y$ can only have values of 0 and 1 , it cannot be explained by a linear regression model. However, a probit model can show the probability of $Y$ falling between 0 and 1 based on a cumulative normal distribution given any $Z$-score, with $(Z) €[0,1]$.

Thus, it can be stated that:

$$
\begin{aligned}
& Y=\phi\left(\mathrm{X} \beta^{\prime}+\varepsilon^{\prime}\right), \\
& \phi^{-1}(Y)=X \beta^{\prime}+\varepsilon^{\prime}, \\
& \mathbf{Y} *=\mathbf{X} \beta^{\prime}+\varepsilon^{\prime} .
\end{aligned}
$$

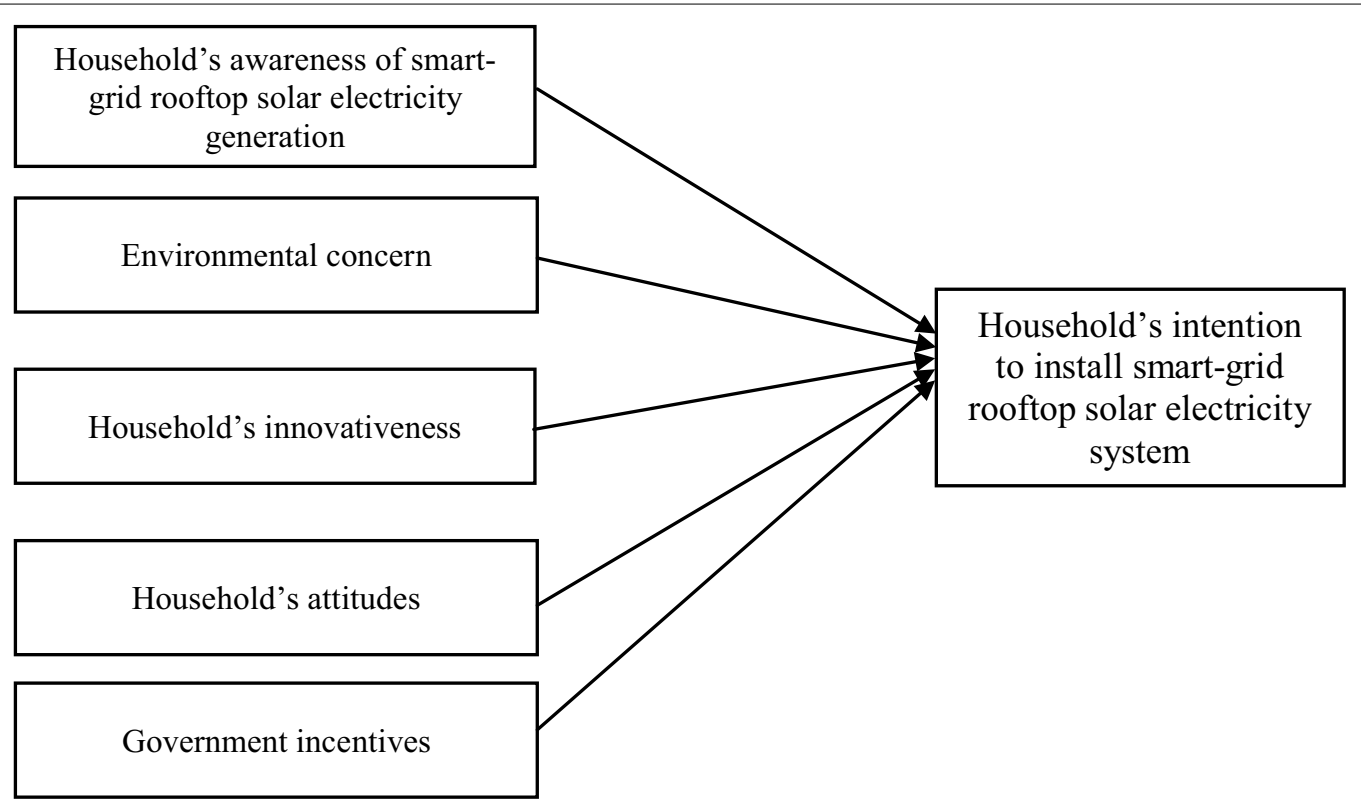

Fig. 2 Research model [40-42] 
Table 1 Items used to measure independent variables

\begin{tabular}{|c|c|}
\hline Variable measured & Explanation and items \\
\hline Household_awareness & Households' awareness of smart grid rooftop solar electricity \\
\hline Awareness1 & 1. A smart grid rooftop solar electricity system will provide electricity for my family during the day \\
\hline Awareness2 & 2. I will reduce my monthly electricity bill by installing a smart grid rooftop solar system \\
\hline Awareness3 & 3. I believe that smart grid rooftop solar electricity will be the source of power in the future \\
\hline Awareness4 & 4. A smart grid solar rooftop system can generate electricity in the winter \\
\hline Awareness 5 & 5. A smart grid rooftop solar system can increase the lifespan of the roof by protecting it from external factors \\
\hline Environmental_concern & The household's concern about the environmental protection aspects of smart grid rooftop solar energy systems \\
\hline Environmental_concerning1 & 1. Smart grid rooftop solar energy can help to protect the environment \\
\hline Environmental_concerning2 & 2. If I instal a smart grid rooftop solar electricity system, I will contribute to the preservation of nature and humanity \\
\hline Environmental_concerning3 & 3. The owner of a smart grid rooftop system can feel better because they do not harm the environment \\
\hline Household_innovativeness & The household's innovativeness in relation to new energy resources \\
\hline Household_innovativeness1 & 1. If I knew that a smart grid rooftop solar electricity system was available, I would be interested in trying it \\
\hline Household_innovativeness2 & 2. I have discovered more information about smart grid solar rooftop electricity installation services than my friends \\
\hline Household_innovativeness3 & 3. I would instal a smart grid rooftop solar system even though none of my friends had tried one before me \\
\hline Household_attitude & Attitude toward installing a rooftop solar electricity system \\
\hline Household_attitude1 & 1. I believe that smart grid rooftop solar electricity is a good and reliable investment in the long-term \\
\hline Household_attitude2 & 2. I believe that a smart grid rooftop solar electric system will raise the utility of my house \\
\hline Household_attitude3 & 3. I believe that smart grid rooftop solar electricity can decrease global warming, so, it is good for the environment \\
\hline Government_incentive & Government incentives relating to smart grid rooftop solar electricity \\
\hline Government_incentive1 & 1. I think that the Vietnamese government policies encouraging rooftop solar electricity are good \\
\hline Government_incentive2 & $\begin{array}{l}\text { 2. The government now provides a 20-year feed-in tariff to buy back electricity from rooftop PV at } 9.35 \text { US cent/kWh, } \\
\text { which is attractive to me }\end{array}$ \\
\hline Government_incentive3 & $\begin{array}{l}\text { 3. I think that incentive policies for rooftop solar electricity will encourage people to instal rooftop solar electricity on } \\
\text { their houses }\end{array}$ \\
\hline Government_incentive4 & 4. I think that incentive policies for rooftop solar electricity will continue into the future \\
\hline
\end{tabular}
Source: [40-42]

Here, $\varepsilon^{\prime} \sim N\left(0, \sigma^{2}\right)$, where $Y^{*}$ ranges from $-\infty$ to $\infty$. $Y^{*}$ is also called a latent variable.

Whether or not a family intends to instal a rooftop solar electric system can be expressed as the relationship between the linear regression model (Eq. 1) and the latent variable (Eq. 2) as follows: where $\emptyset$ is the cumulative standard normal distribution function.

The conditional chance of $Y=0$ (i.e. prefers not to instal a solar electricity system) is given by:

$Y=0$ if $Y *<0$ (the household is not likely to instal a solar electricity system),

$Y=1$ if $Y *>=0$ (the household is likely to instal a solar electricity system).

Thus, a probit model was used to estimate the probability of people installing a solar electricity system.

The conditional probability of customer i, being likely to instal a solar electricity system (i.e. $\mathrm{Yi}=1$ ) given $\mathrm{xi}$, is expressed as:

$$
P(Y i=0 \mid x i)=1-\emptyset\left(\frac{-\beta^{\prime} x i}{\sigma_{1}}\right)
$$

$$
\left.P(\mathrm{Yi}=1)=P(Y i=1 \mid x i)=P\left(\beta^{\prime} x i+\varepsilon_{1 i} \geq 0\right) \mid x i\right)=P\left(\frac{\varepsilon_{i}}{\sigma} \geq \frac{-\beta^{\prime} x i}{\sigma}\right)=\emptyset\left(\frac{-\beta^{\prime} x i}{\sigma_{1}}\right),
$$




$$
\prod_{I=}^{N_{1}}\left[\varnothing\left(\frac{-\beta^{\prime} x i}{\sigma_{1}}\right)\right] \cdot \prod_{N_{1}-1}^{N}\left[1-\emptyset\left(\frac{-\beta^{\prime} x i}{\sigma_{1}}\right)\right],
$$

where N1: household wants to instal a rooftop solar system, and N-N1: household does not want to instal a rooftop solar system.

In this model, a higher value of $\beta^{\prime} i$ indicates that the household is more likely to instal a solar electricity system. The value of $\beta$ 'i indicates that a one-unit change in $\mathrm{Xi}$ leads to a $\beta$ 'i change in the Z-score of probability Y. The SPSS v.20 software program was used to calculate the probabilities and to conduct other statistical analyses.

\section{Determination of reliability}

The reliability of the items in the research instrument through which the data were measured was determined using Cronbach's alpha, and the corrected item-total correlation. Cronbach's alpha is a coefficient of coherence that shows the close connection of items to a group. The purpose of Cronbach's alpha is to determine if the observed variables measure the same for a concept that is being measured. The contribution of the variables is reflected by the corrected item-total correlation, whereby it is allowed to eliminate inappropriate variables in the research model. The reliability is considered acceptable if the Cronbach's alpha is $\geq 0.7$, and the corrected item-total correlation is $>0.3$ [44].

\section{Exploratory factor analysis}

An exploratory factor analysis (EFA) was used to determine the factors that affect the intention of households to instal rooftop solar electricity generation systems. The conditions of the analysis were as follows:

Factor loading $>0.5$ and Kaiser-Meyer-Olkin (KMO) $0.5 \leq \mathrm{KMO} \leq 1$

Bartlett test $($ Sig. $<0.05)$ and the average variance extracted $>50 \%$; and

Variables with $\mathrm{KMO}<0.5$ were removed from the model [44].

\section{Multicollinearity diagnostics}

Multicollinearity is the phenomenon of independent variables strongly correlating with each other. A regression

Table 2 Profile of respondents

\begin{tabular}{|c|c|c|c|}
\hline & Category & Frequency & Percentage \\
\hline & Total (households) & 300 & 100 \\
\hline \multirow[t]{2}{*}{ Gender } & Female & 147 & 49.0 \\
\hline & Male & 153 & 51.0 \\
\hline Marital status & Married & 300 & 100 \\
\hline \multirow[t]{5}{*}{ Education } & Primary school & 0 & 0 \\
\hline & Secondary school & 2 & 0.7 \\
\hline & High school & 160 & 53.3 \\
\hline & College & 102 & 34.0 \\
\hline & Postgraduate & 36 & 12.0 \\
\hline Smart grid rooftop solar system status & $\begin{array}{l}\text { Do not have a rooftop solar electricity } \\
\text { system }\end{array}$ & 300 & 100 \\
\hline \multirow[t]{6}{*}{ Level of electricity consumption } & From 0 to $50 \mathrm{kWh}$ & 0 & 0 \\
\hline & From 51 to $100 \mathrm{kWh}$ & 49 & 16.3 \\
\hline & From 101 to $200 \mathrm{kWh}$ & 119 & 39.7 \\
\hline & From 201 to $300 \mathrm{kWh}$ & 87 & 29.0 \\
\hline & From 301 to $400 \mathrm{kWh}$ & 31 & 10.3 \\
\hline & Over 400 kWh & 14 & 4.7 \\
\hline \multirow[t]{5}{*}{ Age } & From 20 to 30 years old & 7 & 2.3 \\
\hline & From 31 to 40 years old & 109 & 36.3 \\
\hline & From 41 to 50 years old & 125 & 41.7 \\
\hline & From 51 to 60 years old & 55 & 18.3 \\
\hline & Over 60 years old & 4 & 1.3 \\
\hline
\end{tabular}


model with multicollinearity will render the results of quantitative analysis not meaningful and incorrect. Variance inflation factors (VIFs), which measure collinearity and tolerance, were applied in this research to determine the multicollinearity phenomenon. Menard [45] stated that a tolerance of below 0.20 is a major concern, while a tolerance of just under approximately 0.10 probably implies a severe collinearity problem. Because a VIF is the opposite of the tolerance, a tolerance of 0.20 relates to the rule of 5 and a tolerance of 0.10 to the rule of 10 [46]. Hair et al. [47] proposed that a VIF of less than 10 is representative of irrelevant collinearity [48]. Kennedy [49] claimed that a VIF > 10 indicates harmful collinearity for standardized results [50].

Table 3 Reliability statistics

\begin{tabular}{|c|c|c|c|c|c|}
\hline & \multicolumn{2}{|c|}{ Scale mean if item deleted } & \multirow{2}{*}{$\begin{array}{l}\text { Scale variance if item } \\
\text { deleted }\end{array}$} & \multirow{2}{*}{$\begin{array}{l}\text { Corrected item-total } \\
\text { correlation }\end{array}$} & \multirow{2}{*}{ 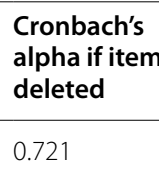 } \\
\hline Awareness1 & 14.02 & & & & \\
\hline Awareness2 & 13.71 & & 10.314 & 0.651 & 0.460 \\
\hline Awareness3 & 14.02 & & 12.284 & 0.197 & 0.684 \\
\hline Awareness4 & 13.69 & & 10.557 & 0.616 & 0.478 \\
\hline Awareness5 & 13.56 & & 10.996 & 0.533 & 0.516 \\
\hline \multicolumn{3}{|c|}{ Cronbach's alpha of the first factor } & & & 0.634 \\
\hline Environmental_concern1 & 7.32 & & 4.687 & 0.707 & 0.866 \\
\hline Environmental_concern2 & 6.94 & & 4.748 & 0.768 & 0.804 \\
\hline Environmental_concern3 & 6.95 & & 4.984 & 0.793 & 0.787 \\
\hline \multicolumn{5}{|c|}{ Cronbach's alpha of the second factor } & 0.871 \\
\hline Innovativeness 1 & 6.17 & & 2.344 & 0.729 & 0.787 \\
\hline Innovativeness2 & 6.11 & & 2.031 & 0.740 & 0.770 \\
\hline Innovativeness3 & 6.07 & & 2.105 & 0.696 & 0.813 \\
\hline \multicolumn{5}{|c|}{ Cronbach's alpha of the third factor } & 0.849 \\
\hline Household_attitude1 & & 6.39 & 2.019 & 0.809 & 0.801 \\
\hline Household_attitude2 & & 6.60 & 2.274 & 0.748 & 0.854 \\
\hline Household_attitude3 & & 6.53 & 2.357 & 0.764 & 0.841 \\
\hline \multicolumn{5}{|c|}{ Cronbach's alpha of the fourth factor } & 0.882 \\
\hline Government_incentive1 & & 11.14 & 4.776 & 0.647 & 0.768 \\
\hline Government_incentive2 & & 11.06 & 4.491 & 0.633 & 0.773 \\
\hline Government_incentive3 & & 11.13 & 4.619 & 0.628 & 0.775 \\
\hline \multicolumn{5}{|c|}{ Cronbach's alpha of the fifth factor } & 0.817 \\
\hline
\end{tabular}

Source: calculation based on the survey

Table 4 Cronbach's alpha of the first factor after removal of items, Awareness 1 and Awareness3

\begin{tabular}{lllll}
\hline & Scale mean if item deleted & Scale variance if item deleted & $\begin{array}{l}\text { Corrected item-total } \\
\text { correlation }\end{array}$ & $\begin{array}{l}\text { Cronbach's alpha } \\
\text { if item deleted }\end{array}$ \\
\hline Awareness2 & 7.25 & 4.329 & 0.798 & 0.816 \\
Awareness4 & 7.23 & 4.457 & 0.768 & 0.843 \\
Awareness5 & 7.10 & 4.421 & 0.760 & 0.850 \\
Cronbach's alpha of the first factor & & & 0.884 \\
\hline
\end{tabular}

Source: calculation based on the survey 
Table 5 Multicollinearity diagnostics

\begin{tabular}{|c|c|c|c|c|c|c|c|c|}
\hline \multicolumn{9}{|c|}{ Coefficients $^{a}$} \\
\hline \multicolumn{2}{|c|}{ Model } & \multicolumn{2}{|c|}{ Unstandardized coefficients } & \multirow{2}{*}{$\begin{array}{l}\text { Standardized } \\
\text { coefficients } \\
\text { Beta }\end{array}$} & \multirow[t]{2}{*}{$t$} & \multirow[t]{2}{*}{ Sig. } & \multicolumn{2}{|c|}{ Collinearity statistics } \\
\hline & & B & Std. error & & & & Tolerance & VIF \\
\hline \multirow[t]{6}{*}{1} & (Constant) & -1.542 & 00.152 & & -10.153 & 0.000 & & \\
\hline & Awareness & 0.149 & 0.023 & 0.323 & 6.498 & 0.000 & 0.823 & 1.214 \\
\hline & Environmental_concerning & 0.067 & 0.022 & 0.151 & 3.080 & 0.002 & 0.842 & 1.187 \\
\hline & Customer_innovativeness & 0.097 & 0.032 & 0.145 & 3.038 & 0.003 & 00.889 & 1.125 \\
\hline & Attitude & 0.145 & 0.033 & 0.222 & 4.379 & 0.000 & 0.787 & 1.270 \\
\hline & Government_incentive & 0.091 & 0.033 & 0.133 & 2.770 & 0.006 & 0.880 & 1.136 \\
\hline
\end{tabular}

${ }^{a}$ Dependent variable: WTP

\section{Results}

\section{Profile of respondents}

The study was conducted with a sample of 300 households in the Daklak province, of which $51 \%$ were males, and $100 \%$ were married. The electricity consumption for the majority of the people was at levels 3 and 4, with percentages of $39.7 \%$ and $29 \%$, respectively. The detailed information of the respondents is given in Table 2 .

Table 6 Rotated component matrix

\begin{tabular}{llllll}
\hline & \multicolumn{3}{l}{ Component } & & \\
\cline { 2 - 5 } & $\mathbf{1}$ & $\mathbf{2}$ & $\mathbf{3}$ & $\mathbf{4}$ & $\mathbf{5}$ \\
\hline Government_incentive4 & 0.816 & & & & \\
Government_incentive2 & 0.789 & & & & \\
Government_incentive3 & 0.782 & & & & \\
Government_incentive1 & 0.776 & & & & \\
Awareness2 & & 0.894 & & & \\
Awareness4 & 0.875 & & & \\
Awareness5 & 0.853 & & & \\
Environmental_concern2 & & & 0.890 & & \\
Environmental_concern3 & & & 0.869 & & \\
Environmental_concern1 & & & 0.845 & & \\
Household_attitude1 & & & & 0.905 & \\
Household_attitude2 & & & & 0.852 & \\
Household_attitude3 & & & & 0.832 & \\
Customer_innovativeness2 & & & & & 0.877 \\
Customer_innovativeness1 & & & & & 0.862 \\
Customer_innovativeness3 & & & & & 0.849 \\
\hline
\end{tabular}

Source: calculation based on the survey

\section{Factor analysis} Reliability statistics

Before analysing the factors that affected the intention to instal a smart grid rooftop solar electricity system, the Cronbach's alpha was calculated to test the reliability of each of the items in the survey.

The reliability was considered acceptable if the Cronbach's alpha was $\geq 0.7$, and the corrected item-total correlation was $>0.3$ [44] As can be observed from Table 3, the reliability of all the items in the survey was acceptable except for the items, Awareness1 and Awareness3. Removing those two items from the model and repeating the process produced the revised Cronbach's alpha for factor 1 , as shown in Table 4 .

After removing the two items, all the variables were considered to be suitable for the model. An EFA was, therefore, conducted with all the variables without Awareness 1 and Awareness3.

\section{Exploratory factor analysis}

In this study, the KMO was found to be equal to 0.785 , with the significance of the Bartlett test being equal to 0.000 , and the sum of the variance extracted being $76.791 \%$. All the factor loadings were higher than 0.5 , as illustrated in the rotated component matrix illustrated in Table 6.

\section{Multicollinearity diagnostics}

The results would be incorrect and would not be meaningful if there was multicollinearity. Therefore, the study had to be diagnosed for multicollinearity before any analysis could be performed. As shown in Table 5, all the VIFs were well under 5 , and the tolerance was greater than 0.2 . Therefore, there was no multicollinearity in the model. Thus, all the variables were appropriate for analysis. 
Table 7 Categorical variable information

\begin{tabular}{|c|c|c|c|c|}
\hline & & & $N$ & Percent (\%) \\
\hline \multirow[t]{3}{*}{ Dependent variable } & Intention_to_instal & Do not intend to instal & 201 & 67.0 \\
\hline & & Intend to instal & 99 & 33.0 \\
\hline & & Total & 300 & 100.0 \\
\hline
\end{tabular}

Source: calculation based on the survey

Table 8 Parameter estimates

\begin{tabular}{lcccccc}
\hline Parameter & $\beta^{\prime}$ & Std. error & $Z$ & Sig. & \multicolumn{2}{c}{ 95\% confidence interval } \\
\cline { 5 - 7 } & & & & & Lower bound Upper bound \\
\hline PROBIT & & & & & & \\
Awareness & 0.364 & 0.079 & 0.597 & 0.000 & 0.209 & 0.519 \\
Environmental_concern & 0.140 & 0.070 & 2.004 & 0.045 & 0.003 & 0.278 \\
Household_innovativeness & 0.146 & 0.082 & 1.787 & 0.074 & -0.014 & 0.307 \\
Household_attitude & 0.201 & 0.078 & 2.567 & 0.010 & 0.048 & 0.355 \\
Government_incentive & 0.256 & 0.098 & 2.606 & 0.009 & 0.064 & 0.449 \\
Intercept & -5.390 & 0.525 & -10.272 & 0.000 & -5.914 & -4.865 \\
\hline
\end{tabular}

${ }^{\text {a }}$ PROBIT model: $\mathrm{PROBIT}(\mathrm{p})=$ intercept $+\beta^{\prime} X$

Source: calculation based on the survey

\section{Probit binary model}

After testing the reliability of the items, conducting the EFA, and removing the results of the items, Awareness1 and Awareness3, from the data, the probit binary model was used to explore the intention of the sample of 300 households to instal a smart grid rooftop solar system. As noted above, the intention to instal was a binary dependent variable with a value of 0 indicating that the people who had no intention of installing a solar electricity system, and a value of 1 indicating a positive intention. As shown in Table 6, the independent variables used in the model were labelled as Household_awareness, Environmental_concern, Household_innovativeness, Attitude, and Government_incentive, which corresponded with the five factors derived from the following items:

$$
\text { Awareness }=\text { mean } \quad \text { (Awareness2, Awareness4, }
$$
Awareness5).

Environmental_concern $=$ mean (Environmental_concern1, Environmental_concern2, Environmental_concern3).

Household_innovativeness $=$ mean (Customer_innovativeness1, Customer_innovativeness2, Customer_innovativeness3).
Household_a $t_{t} i t u d e=\mathrm{m}$ e a $\mathrm{n}$ (Attitude1, Attitude2, Attitude3).

Government_incentive $=$ mean (Government_incentive1, Government_incentive2, Government_incentive3, Government_incentive4).

Table 9 Probability of intention to instal a smart grid rooftop solar electricity system

\begin{tabular}{lcr}
\hline $\begin{array}{l}\text { Probability of intention to instal a smart } \\
\text { grid rooftop solar electricity system }\end{array}$ & $\begin{array}{l}\text { Number of } \\
\text { households }\end{array}$ & $\%$ \\
\hline From 0 to 0.100 & 192 & 64 \\
From 0.101 to 0.200 & 74 & 25 \\
From 0.201 to 0.300 & 15 & 5 \\
From 0.301 to 0.400 & 14 & 5 \\
From 0.401 to 0.500 & 5 & 2 \\
From 0.501 to 0.600 & 0 & 0 \\
From 0.601 to 0.700 & 0 & 0 \\
From 0.701 to 0.800 & 0 & 0 \\
From 0.801 to 0.900 & 0 & 0 \\
From 0.901 to 1.00 & 0 & 0 \\
Total & 300 & 100 \\
\hline
\end{tabular}

Source: calculation based on the survey 
The model that was used to predict the dependent variable was as follows:

\section{Intention to install*}

$$
\begin{aligned}
& =\beta_{0}^{\prime}+\beta_{1}^{\prime}{ }_{1} \text { Household_Awereness }+\beta^{\prime}{ }_{2} \text { Environmental_Concern } \\
& +\beta^{\prime}{ }_{3} \text { Household_Innovativeness }+\beta^{\prime}{ }_{4} \text { Household_attitude } \\
& +\beta_{5}{ }_{5} \text { Government_Incentive } e_{e}+\varepsilon^{\prime}
\end{aligned}
$$

From the total of 300 households, 99, representing 33\% of the surveyed sample, indicated that they intended to instal smart grid rooftop solar systems on their houses (refer to Table 7). However, most households (67\%) had no intention of installing such a system. The reasons that were given by those who did not intend to instal rooftop solar systems varied; some said that they did not have enough money to instal such a system. In contrast, some did not know about rooftop systems and had doubts about their efficiency, and wanted to know what guarantee existed in that such systems would operate as they were intended to.

From the results in Table 8, the Sig. of Customer_innovativeness was 0.74 , which is higher than 0.05 , and thus, the effect of Customer_innovativeness on the intention to instal was not significant. The remaining four Sig. values were all less than 0.05 , and therefore, those four factors had a significant effect on the dependent variable. Most of the coefficient $\beta$ values were positive, with the exception of Intercept $\beta^{\prime} \mathrm{o}$, which means that the effects were all in the same direction, i.e. the effects were all positive. The $\beta$ ' of the awareness variable was the highest, indicating that this factor had the greatest effect on the intention to instal a solar electricity system. Government incentives were also found to be an important factor in the people's

Table 10 Willingness to pay for system installation cost

\begin{tabular}{llc}
\hline & Households & Percent \\
\hline $\begin{array}{l}\text { Willing to pay an installation cost of } 620-744 \\
\text { USD }\end{array}$ & 13 & 13.1 \\
$\begin{array}{l}\text { Willing to pay an installation cost of 1240-1488 } \\
\quad \text { USD }\end{array}$ & 38 & 38.4 \\
$\begin{array}{l}\text { Willing to pay an installation cost of 1850-2220 } \\
\quad \text { USD }\end{array}$ & 34 & 34.3 \\
$\begin{array}{l}\text { Willing to pay an installation cost of 2470-2964 } \\
\text { USD }\end{array}$ & 10 & 10.1 \\
$\begin{array}{l}\text { Willing to pay an installation cost of 3330-3960 } \\
\quad \text { USD }\end{array}$ & 4 & 4.0 \\
\begin{tabular}{l} 
Total \\
\hline
\end{tabular}
\end{tabular}

Source: calculation based on the survey
In fact, most of the people who answered the questionnaire had limited knowledge concerning smart grid rooftop solar electrical systems, and many thought that such systems were only intended to generate hot water via solar power. Therefore, the researcher needed to provide an introduction concerning smart grid solar systems before administering the main survey.

Table 9 shows the probabilities of households deciding to instal smart grid rooftop solar systems in their houses. As can be seen, only $2 \%$ of the sample recorded a probability from 0.401 to 0.500 , and none of the probability measurements exceeded 0.500 . The majority of the probability measurements of the intention to instal solar electricity systems were between 0 and 0.010 . The detailed probabilities of the intention to instal smart grid rooftop solar electricity systems for each household appear in Appendix 2.

It was also indicated that people would be willing to pay (WTP) to instal a rooftop solar electricity system or would encourage other people to do so if there was support from the government. The largest group (39.3\%) of respondents suggested that the government should support $30 \%$ of the installation cost for smart grid rooftop solar electricity systems, with the second-largest group (27\%) supporting the idea that preferential-rate loans should be made available by commercial banks. Other methods of encouraging people to instal smart grid rooftop solar electricity systems that are not detailed in Table 10 included the idea that people should be able to pay for the installation by instalments over a 3 to 5 -year period or that the government should support $50 \%$ of the installation cost. Some people also suggested that there should be more communication activities to provide information about smart grid rooftop solar electricity.

\section{The amount of money that households in the area would} be willing to pay for installing a smart grid rooftop system In the introduction to the questionnaire, the cost of installing a smart grid rooftop solar system was indicated to be in proportion to the level of electricity used 
(see Appendix 1). The households that indicated that they intended to instal such a system were made aware of the cost of installing a system with a generating capacity appropriate for their needs, and they indicated their willingness to pay (WTP) that cost. The breakdown of the amount that the households intending to instal a rooftop solar electricity system were willing to pay (WTP) is shown in Table 10.

\section{Discussion}

\section{Research limitations}

Even though all areas of Vietnam are appropriate for the exploitation of solar energy [20], the current research concentrated on only one area in Vietnam-the Central Highlands, which has the highest potential due to the duration of sunshine it enjoys annually. In addition, only five factors (awareness, environmental concerns, household innovativeness, household attitudes, and government incentives) were considered, with the data being gathered by a series of items measured using a five-point Likert scale, based on which a model was constructed to determine the effects of the independent variables on the intention of households to instal smart grid rooftop solar electricity systems in the research area. Moreover, only those households occupied by married couples and their families were analysed.

\section{Policy implications}

The research provides important information for the Vietnamese government, enabling them to enhance their policy of developing alternative energy resources. Based on the results, the awareness of households of smart grid rooftop solar electricity systems and government incentives were the two most influential factors that affect the intention of the people to instal such systems. Based on these findings, the following two policy measures are proposed for adoption by the government as they are likely to encourage the installation of rooftop electricity generation systems.

Firstly, the Government should identify those households that possess a high awareness concerning rooftop solar power and offer incentives directly to them. The results of this research showed that people with a high level of awareness (i.e. scores of 2.5 to 5 in the Awareness section of the questionnaire) had a higher intention to instal. The Government can also conduct some communication programmes to enhance the awareness of people about rooftop solar electricity so that programmes for the development of alternative energy will be more effective. As happens in Vietnam with every government programme, the People's Committee will disseminate information to the local people through workshops or meetings and hence, should send invitations to households with the potential to instal rooftop solar systems to attend at a particular date and time. At the meeting, experts in smart grid rooftop solar systems should talk about the functionality and usefulness of these systems so that people will clearly understand the benefits. The Chairman of the Committee should then introduce the incentives that are available to the people who have been invited and have attended the meeting.

In terms of government incentives and based on the recommendations made by the respondents in the research area, the following measures are suggested for implementation in the long-term by the Vietnamese government:

- Require commercial banks to offer preferential loans with lower interest rates than for those applying for other forms of credit for the installation of domestic electricity generation systems based on renewable energy sources.

- Offer a monetary gift (e.g., VND 5 million) when people instal a rooftop solar system on their house.

- Subsidize $10-30 \%$ or even $50 \%$ of the installation cost of domestic solar rooftop electricity systems in the same way as support is currently being offered to companies that instal such systems and in a similar way as the Indian government is offering such support in their PV rooftop programme.

- Enhance communication activities concerning smart grid rooftop solar electricity.

\section{Conclusion}

The study demonstrated that households have so far installed only a very small number of smart grid rooftop solar electricity systems in the Daklak Province, Vietnam. Moreover, few people are aware of the advantages of using renewable energy resources. However, after the information of rooftop solar electricity systems had been provided in this survey to the respondents in the research area, they understood the concept and 33\% indicated an intention to instal such a system in their house, with the majority willing to pay (WTP) between USD 1240 and USD 2220. People with a high level of awareness of smart grid rooftop solar power are more likely to pay to instal such a system, but government incentives and household attitudes are also important factors to consider that influence the intention to instal. However, it was found that environmental concerns and the innovativeness of households were less influential factors. 


\section{Appendix 1. Questionnaire: intention to instal smart grid rooftop solar system in Daklak province- Vietnam}

\section{BEFORE THE SURVEY}

\section{Check if the household has a rooftop appropriate for a smart-grid rooftop solar installation}

The survey will only be conducted with households where the rooftop of their house or apartment has a lot of sunshine throughout the day and the roof is not obscured by other houses or by big trees. Therefore, the researcher has to observe before going inside and conducting the survey. The people who answer the question must be above 18 years old.

After observing the rooftop, ask the following question:

(Because the research concentrates on households who have a rooftop appropriate for installing a solar power system, besides observing the house, the area of the rooftop and the electricity consumption should be established in advance.)

1. How much do you pay for electricity every month? ...

2. How big is your rooftop in square meters?

If people do not have an appropriate rooftop area, the survey should stop here.

If people have an appropriate rooftop area, the survey can continue.

3. What is your rooftop made from?

$\square$ Corrugated iron $\square$ Tiles $\square$ Flat concrete $\square$ Other

Have you installed a rooftop solar electricity system in your house?

$\square$ Yes

$\square$ No

If people answer 'yes', then ask them when they installed that system. Is it an off-grid, hybrid or smart-grid system? (If people hesitate before answering, the researcher should give a brief explanation of off-grid and hybrid systems to the respondent to help them to understand). How much did they pay for that the system?

These questions are just used for collecting information, but at this point, stop the survey.

If they answer no, then continue the survey.

Ask them the question: What do you know about smart grid rooftop solar electricity systems?

If they have knowledge of smart-grid systems then turn to the questionnaire and conduct the survey to collect data.

If they say they know little or nothing about smart-grid systems, then give them the introduction before turning to the questionnaire.

Introduction about smart-grid rooftop solar electricity systems.

A smart grid system includes solar panels, an inverter, and two-way metering. Its operation depends on the grid so it is called a smart grid-tie solar electric system. The smart grid will help the solar system operate stably and smoothly in the following ways:

- When the capacity generated by the system < customer's electricity needs, the inverter will take the excess power needed from the grid

- When the capacity generated by the solar electrical system = customer's electricity needs, the power which is generated by the solar electrical system will be used totally for the customer's needs. 
- When the capacity generated by the solar electricity system $>$ the electricity needs of the customer, the surplus power will be sent to the grid.

This process occurs automatically every day without the intervention of the consumer. The surplus electricity generated by the solar electrical system and the power needed from the grid is measured by a two-way meter and the process is termed "net metering". The customers can also sell electricity independently from that which they buy at an FIT price of $9.35 \mathrm{USD} / 1 \mathrm{kWh}$ which is guaranteed for 20 years.

The lifetime of the system is 25 years.

Smart-grid solar rooftop systems are common in Vietnam because they are cheaper than off-grid systems and the customers do not have to buy and replace a battery every 2 to 5 years. EVN will record the net metering and calculate the electric bill for their customers.

The smart-grid solar rooftop energy system is easy to use in the Central Highlands because $95.17 \%$ of households in this area already have grid electricity in their houses.

The advantage of smart-grid solar systems is the lower cost of installation. Unused solar power will be sold to the grid and paid for by EVN. However, when the mains electricity power is lost, the system also stops supplying power to the grid to protect the system and the grid.

A $1 \mathrm{kWp}$ rooftop solar system in Vietnam costs about 1000-1200USD. The duration of sunshine in the Central Highlands of Vietnam is 2000-2600 hours/per year. Therefore, a $1 \mathrm{kWp}$ rooftop solar electricity system can generate at least 2000/365 $=5.4(\mathrm{kWh})$ electricity to meet the consumer's needs if installed in the Central Highlands. The $\mathrm{kWp}$ that is appropriate for different levels of electricity consumption is as follows:

\begin{tabular}{|l|l|l|l|l|l|l|}
\hline $\begin{array}{l}\text { 1. Grid electricity used } \\
\text { monthly }\end{array}$ & $0-50 \mathrm{kWh}$ & $\begin{array}{l}51- \\
100 \mathrm{kWh}\end{array}$ & $\begin{array}{l}101- \\
200 \mathrm{kWh}\end{array}$ & $\begin{array}{l}201- \\
300 \mathrm{kWh}\end{array}$ & $301-400 \mathrm{kWh}$ & $\begin{array}{l}401- \\
500 \mathrm{kWh}\end{array}$ \\
\hline $\begin{array}{l}\text { 2. Electricity bill every month } \\
\text { (USD) }\end{array}$ & $\leq 3.92$ & $\leq 8.10$ & $\leq 18.81$ & $\leq 35.52$ & $\leq 52.92$ & $\leq 68.33$ \\
\hline $\begin{array}{l}\text { 3. Area of rooftop - (6- } \\
\left.7 \mathrm{~m}^{2} / 1 \mathrm{kWp}\right)\left(\mathrm{m}^{2}\right)\end{array}$ & $6-7$ & $6-7$ & $7-8$ & $11-13$ & $15-18$ & $20-24$ \\
\hline $\begin{array}{l}4 . \text { Smart-grid instalation cost } \\
\text { (USD) [(4)*1000 or } 1200]\end{array}$ & $300-360$ & $620-744$ & $1,240-1,488$ & $1,850-2,220$ & $2,470-2,964$ & $3330-3960$ \\
\hline
\end{tabular}

\begin{tabular}{l|l|l|l|l|l|l} 
(USD) $[(4) * 1000$ or 1200$]$ & $300-360$ & $620-744$ & $1,240-1,488$ & $1,850-2,220$ & $2,470-2,964$ & 33 \\
\hline
\end{tabular}

Rooftop solar power does not attract special consumption tax and the personal income tax and VAT rates are zero if the investment income is less than USD 4,244 per year. The personal income tax rate is $0.5 \%$ and VAT is $1 \%$ if the investment income is greater than USD 4,244 per year. Rooftop solar power projects with a capacity of less than $50 \mathrm{kWp}(<01 \mathrm{MW})$ are exempted from the need for an electricity operation license.

According to Circular 302/2016/TT-BTC, there is no excise duty on an investment that produces an income lower than 100 million VND. Income from 100-300 million VND is subject to a duty of 300,000 VND and in income from 300500 million VND attracts a duty of 500,000 VND. The duty on an income of from 500-1000 million VND is 1000,000 VND.

In this study, the highest electricity consumption is more than $400 \mathrm{kWh}$ (from $400-500 \mathrm{kWh}$ ) which means that the highest solar generation capacity required is $3.33 \mathrm{kWp}$. If people sell all the power generated to the grid the benefit per year in this situation is still well under the threshold of USD 4,244 per year, and would, therefore, attract no personal income tax, no VAT, and no excise duty.

A consumer using all the electricity generated for their own needs, will also not have to pay any tax or duty.

\section{QUESTIONNAIRE}

The questions in this survey concentrate on the intention of households in Daklak Province to install smartgrid rooftop solar electricity systems. People are also encouraged to make suggestions to help energy development in the future.

The results will help the Vietnamese government to improve its policies which encourage people to install rooftop solar systems to reduce their dependence on conventional energy resources.

\section{Part 1.}

This part was started with the questions that explained in table 1 of the main text with five Likert Scale's answer: strongly agree, agree, neutral, disagree, strongly disagree

After people answer the above questions, the authors remind people about the rooftop solar system size that is appropriate for their electricity consumption established in the first part and also remind them of the initial cost of the rooftop solar system.

Then ask them:

1. Do you intend to install a smart-grid rooftop system in your house in the near future?

$\square$ Yes (go on to question 3)

$\square$ No (continue to question 2)

2. Why have you not yet installed a smart-grid rooftop solar electricity system up to now? 
3. What would you recommend the Vietnamese Government should offer to encourage the installation of smart-grid rooftop solar electricity systems besides the FIT of 9.35 US cents?

$\square$ Subsidize $10 \%$ of the installation cost

$\square$ Subsidize $20 \%$ of the installation cost

$\square$ Subsidize $30 \%$ of the installation cost

$\square$ Give a 5-million VND bonus to people who install a system

$\square$ Require commercial banks to give preferential-rate loans

Other

Part 2. Respondents' Social demographics

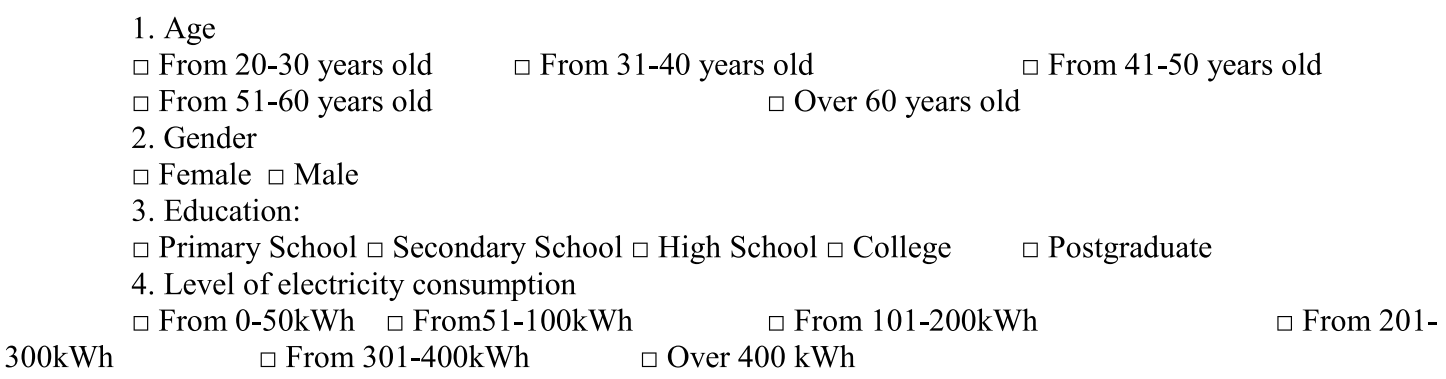

\section{Appendix 2}

See Table 11. 


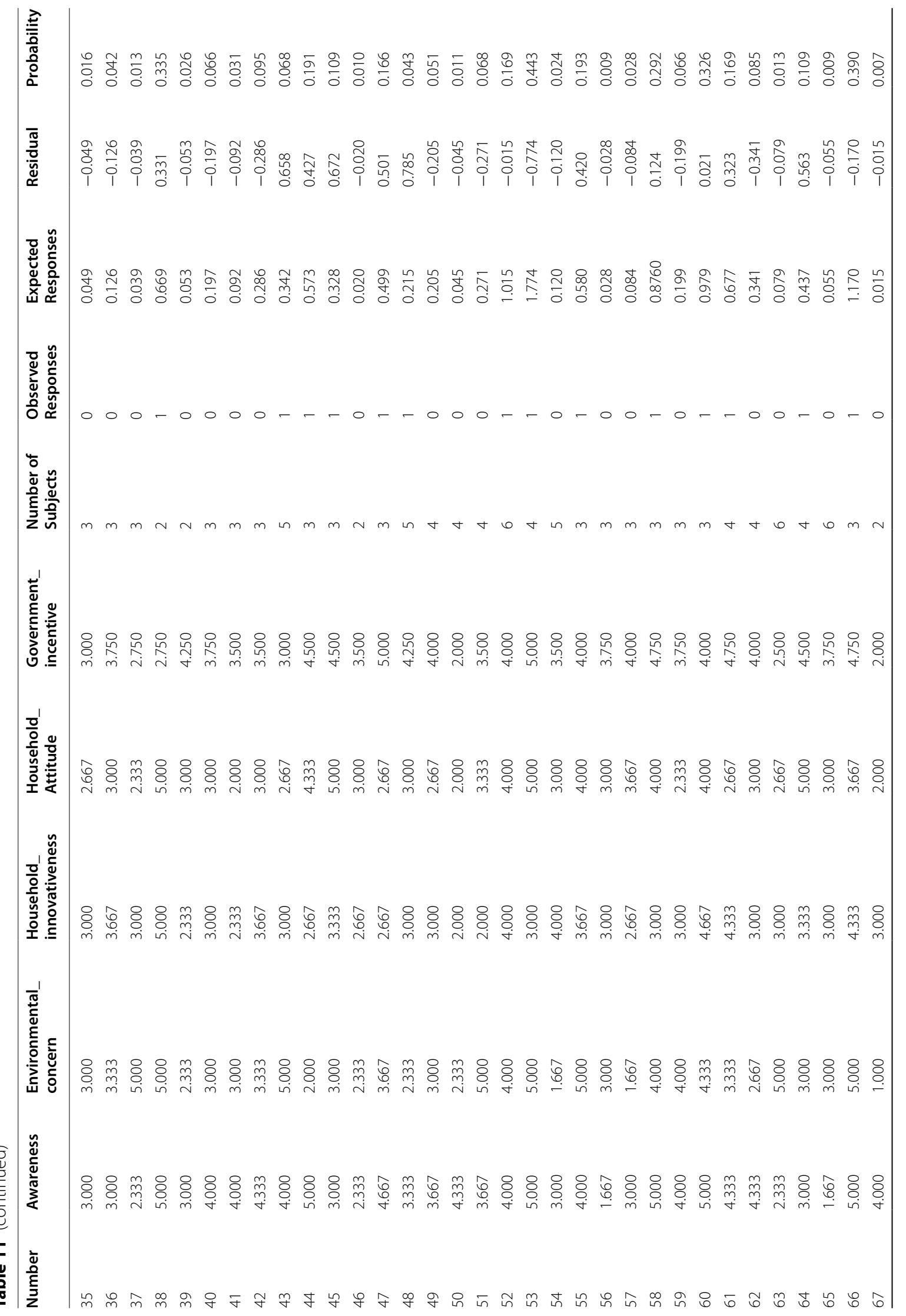




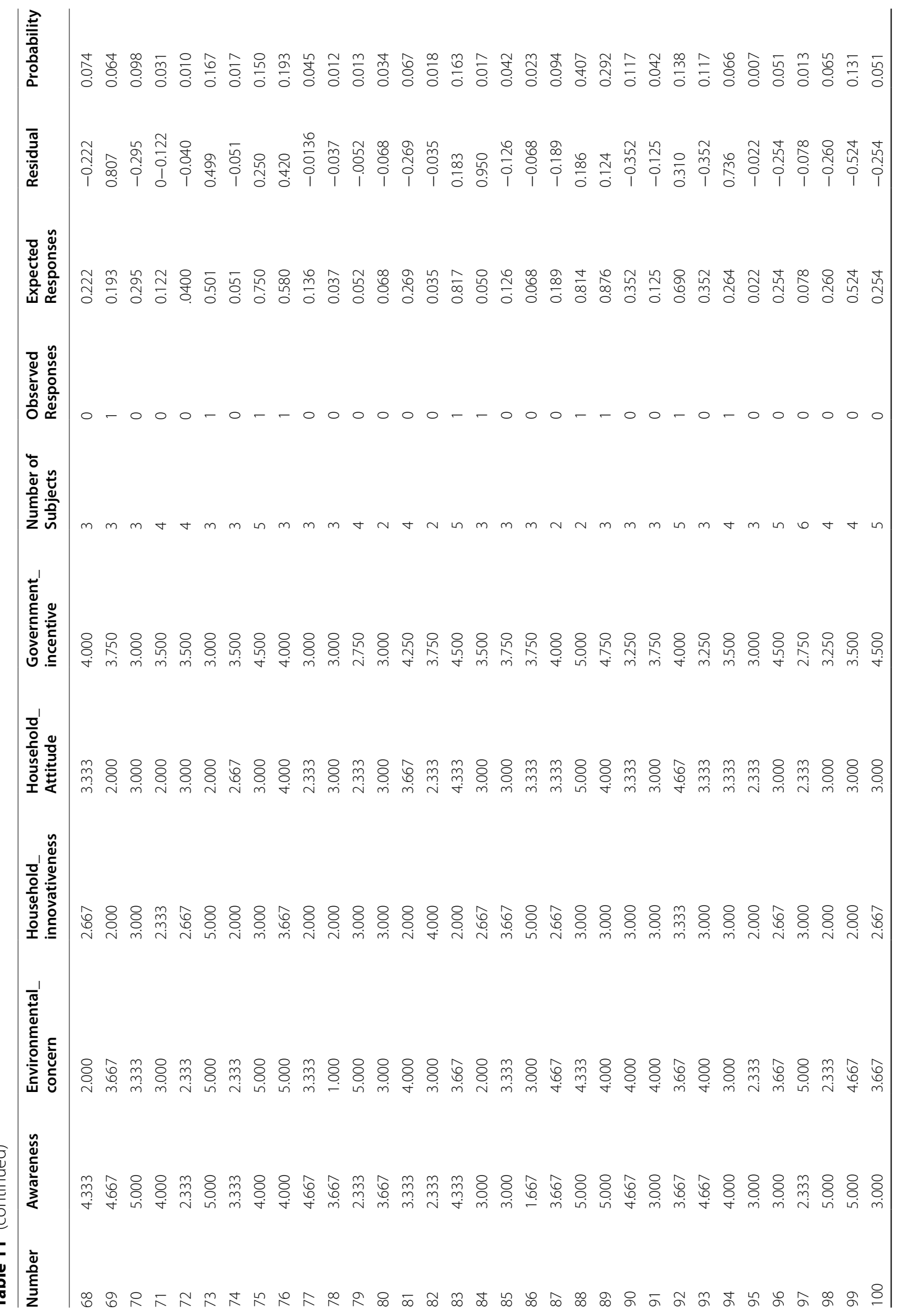




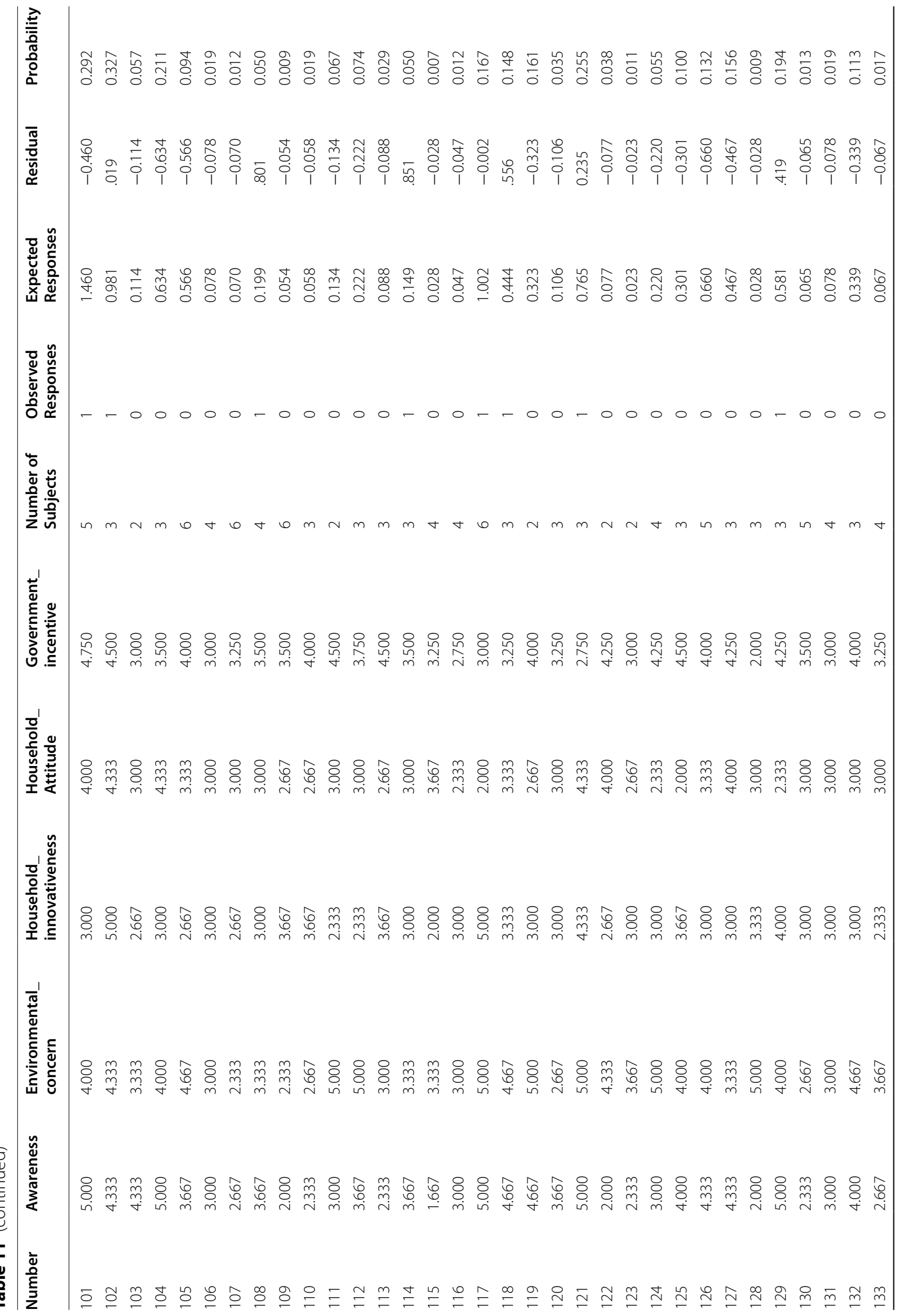




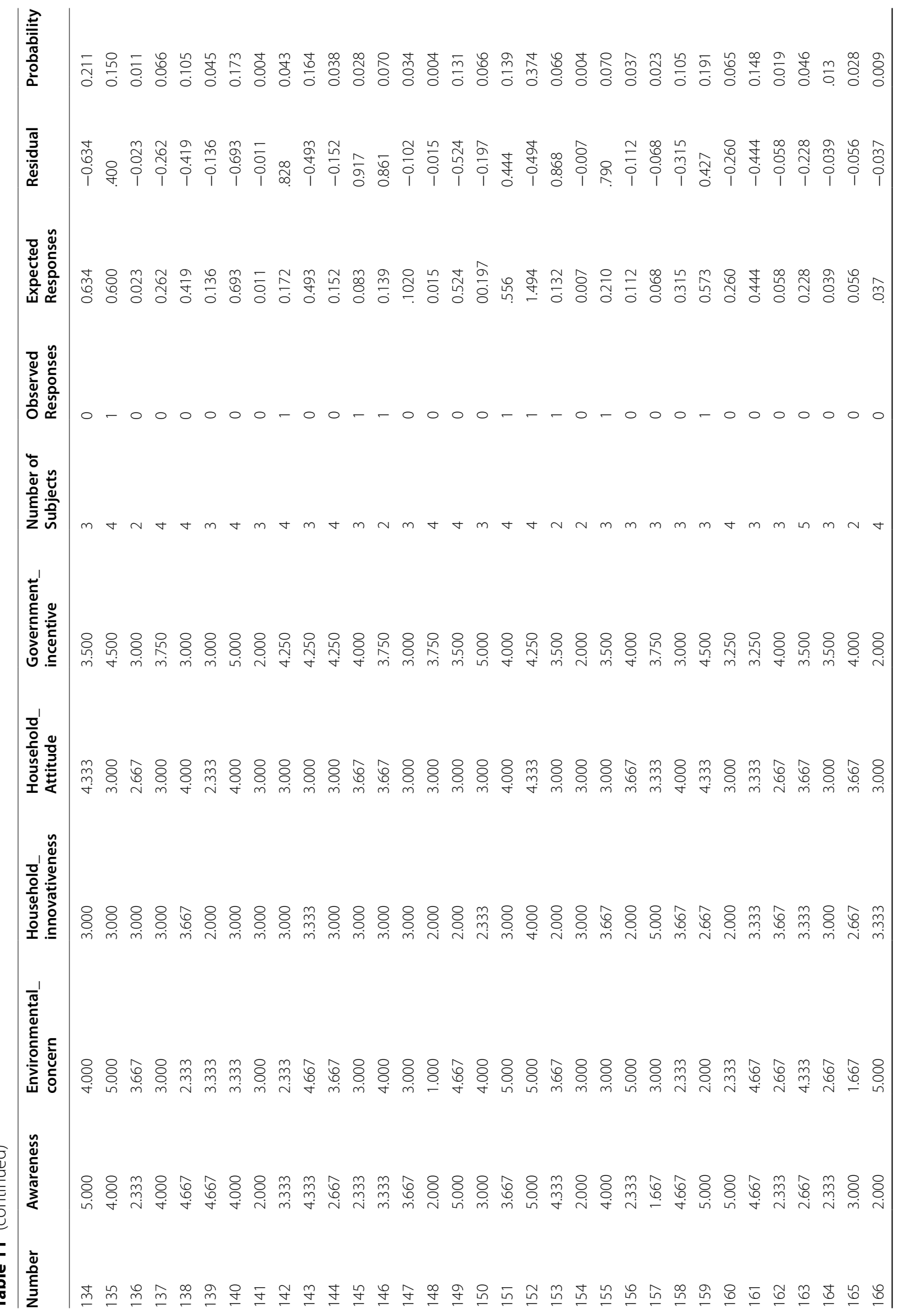




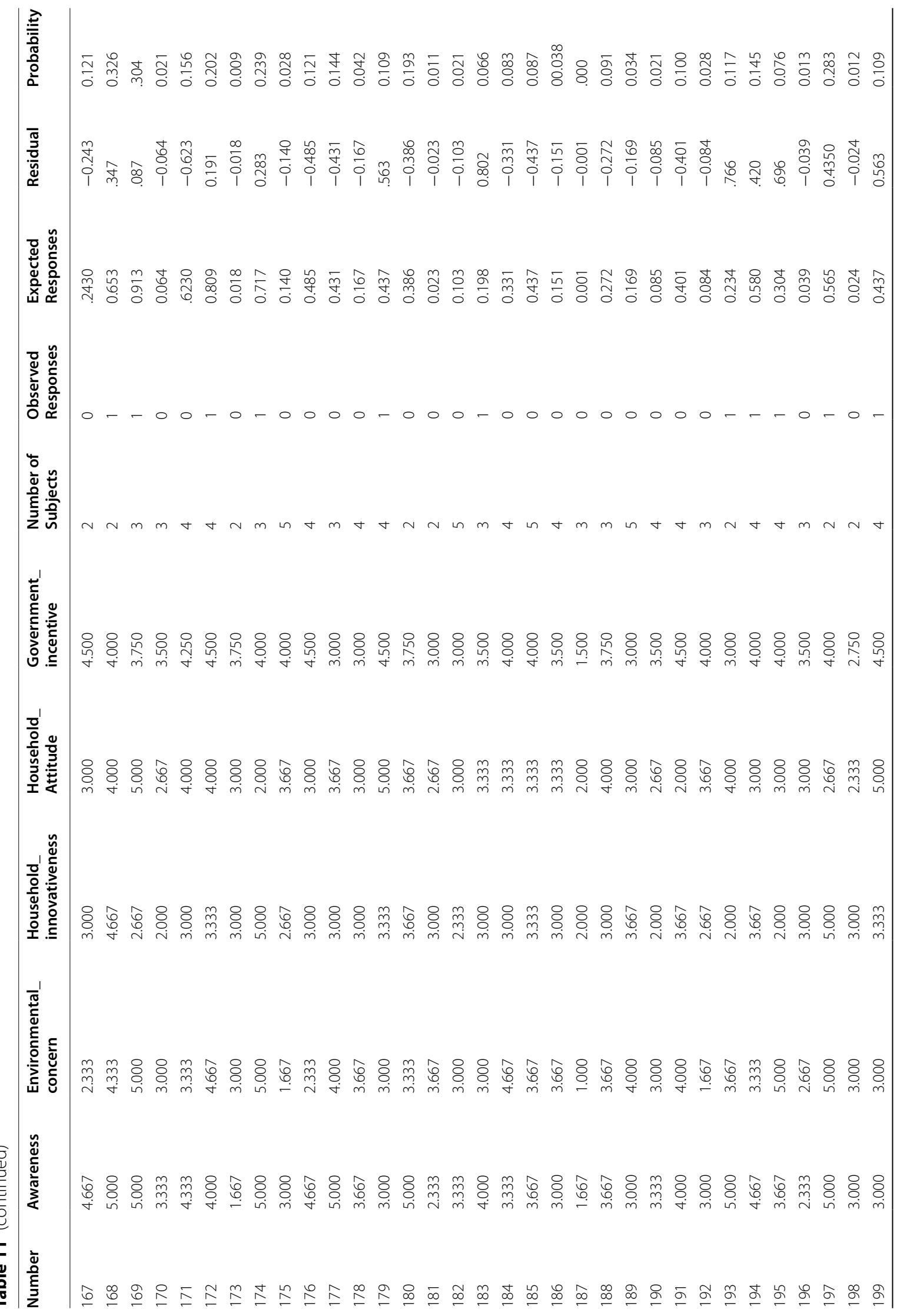




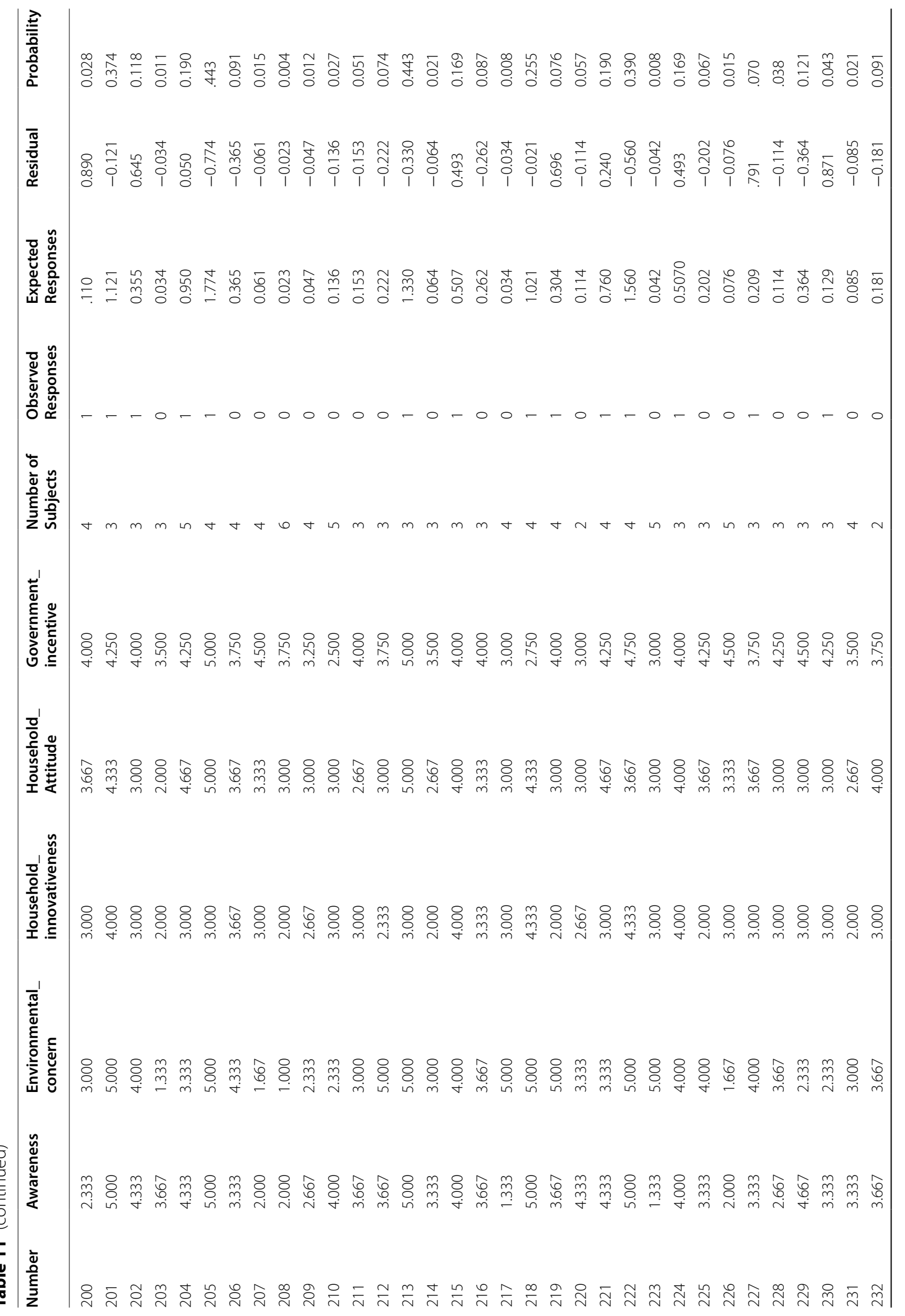




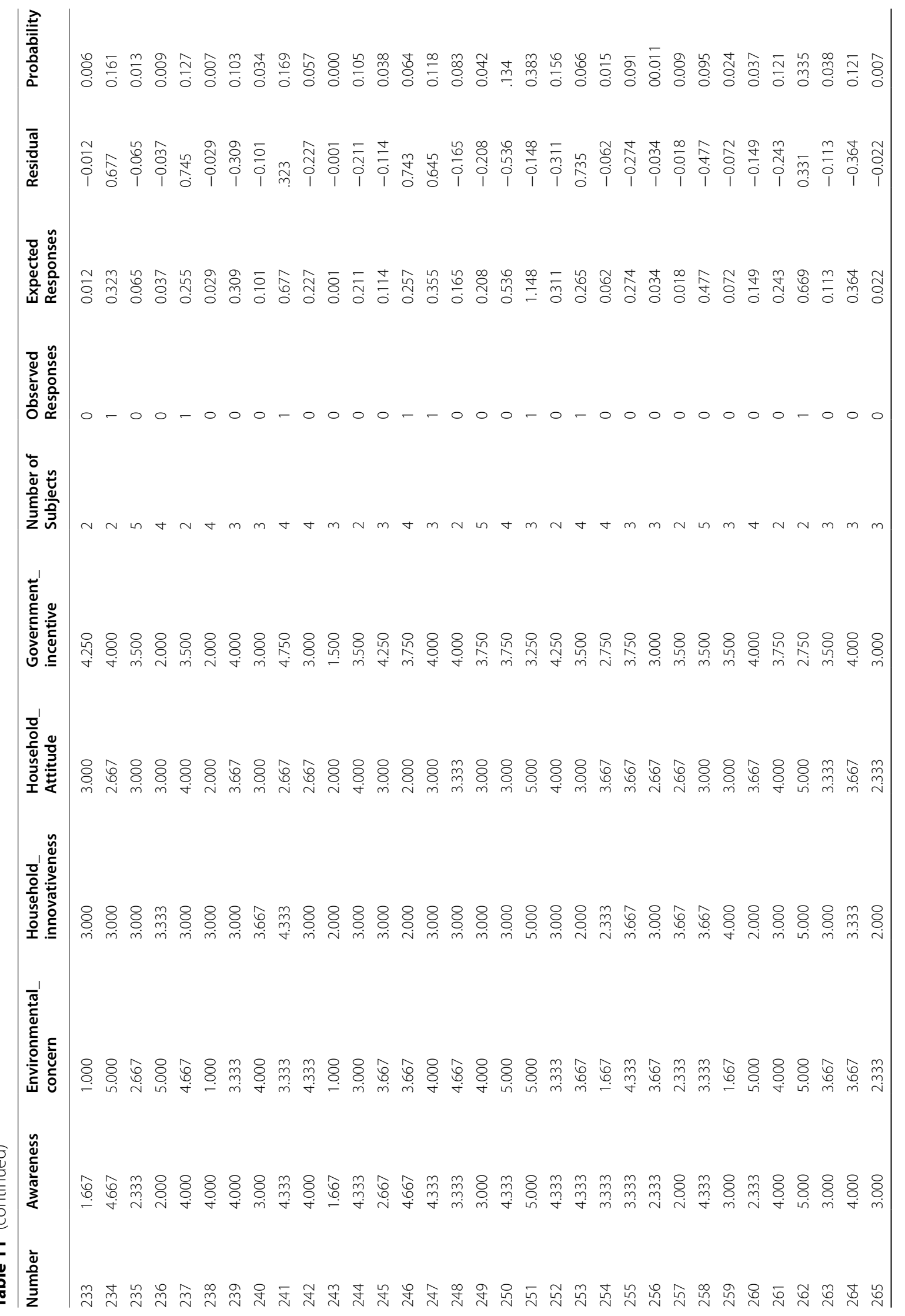




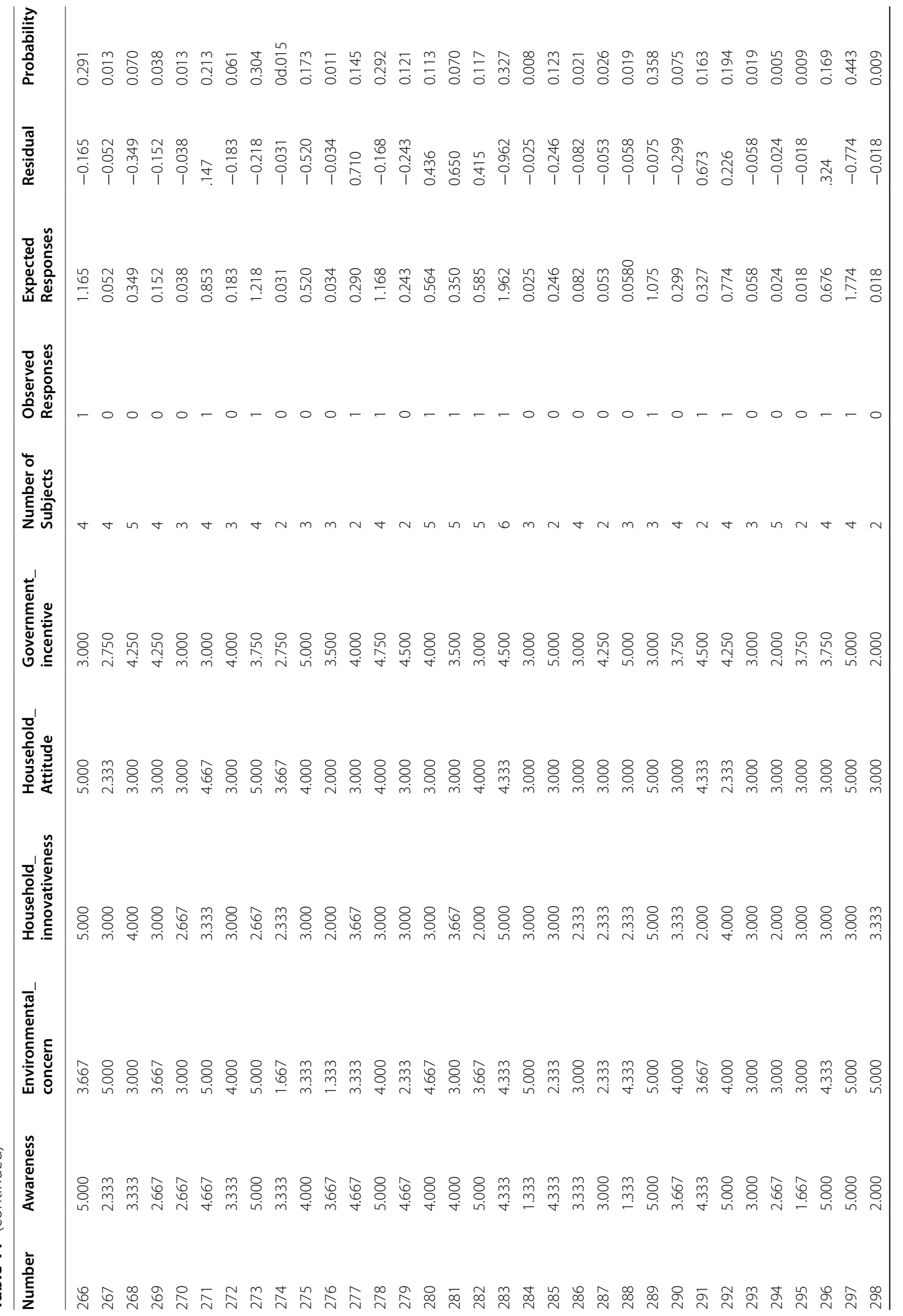




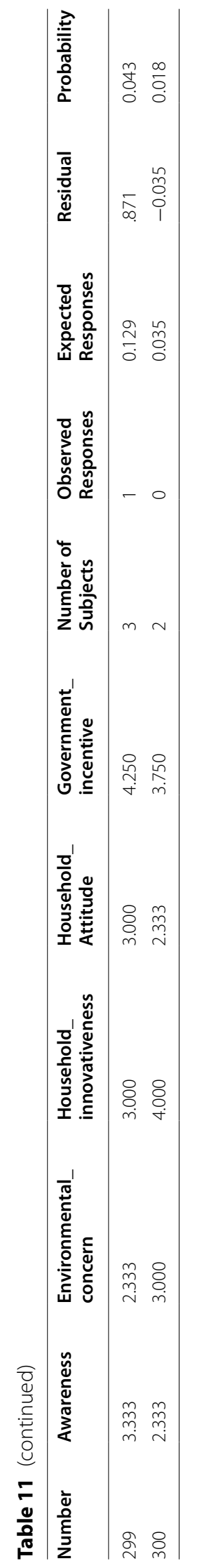




\section{Abbreviations}

FIT: Feed-in-tariff; KM: Kilometre; SG: Smart grid; PVs: Photovoltaic System; EVN: Vietnam Electricity; TPB: Theory of planned behaviour; VIFs: Variance inflation factors; FEA: Exploratory Factor Analysis; WTP: Willing to pay.

\section{Acknowledgements}

This research was supported by Prince of Songkla University under grant Number ENV6402012N.

\section{Authors' contributions}

KT and SJ designed the paper framework and research questions. LDN provided valuable research insights into the analysis. LDN provided valuable research insights into the analysis. LDN and TTL designed the questionnaire, did the survey, wrote and edited the paper; KT and sent the paper to the English Edited Group (RDO-Prince of Songkla University). All authors read and approved the final manuscript

\section{Funding}

Not applicable

\section{Availability of data and materials}

Not applicable.

\section{Declarations}

\section{Ethics approval and consent to participate}

Not applicable.

\section{Consent for publication}

Not applicable.

\section{Competing interests}

The authors declare no conflict interests.

\section{Author details}

${ }^{1}$ Faculty of Environmental Management, Prince of Songkla University, Hat Yai, Songkhla 90112, Thailand. ${ }^{2}$ Faculty of Economics, Tay Nguyen University, 567 Le Duan, Ea Tam, Buon Ma Thuot City, Dak Lak 630000, Vietnam. ${ }^{3}$ Faculty of Economics, Prince of Songkla University, Hat Yai, Songkhla 90112, Thailand. ${ }^{4}$ Environmental Assessment and Technology for Hazardous Waste Management Research Center, Faculty of Environmental Management, Prince of Songkla University, Hat Yai, Songkhla 90112, Thailand.

Received: 6 February 2020 Accepted: 4 June 2021

Published online: 05 July 2021

\section{References}

1. IEA (2018) World Energy Outlook 2018: The future is Electrifying. In: The International Energy Agency. https://www.iea.org/workshops/worldenergy-outlook-2018-the-future-is-electrifying.html. Accessed 25 Feb 2019.

2. Chowdhury MS, Rahman KS, Chowdhury T et al (2020) An overview of solar photovoltaic panels' end-of-life material recycling. Energy Strateg Rev 27:100431. https://doi.org/10.1016/j.esr.2019.100431

3. Tang X (2013) Depletion of fossil fuels and anthropogenic climate change-a review. Energy Policy 52:797-809. https://doi.org/10.1016/j. enpol.2012.10.046

4. Hales AJMREWS (2006) Climate change and human health: present and future risks. Lancet 367:859-869. https://doi.org/10.1016/S0140-6736(06) 68079-3

5. Ellabban O, Abu-Rub H, Blaabjerg F (2014) Renewable energy resources: current status, future prospects, and their enabling technology. Renew Sustain Energy Rev 39:748-764. https://doi.org/10.1016/j.rser.2014.07.113

6. Shafiee S, Topal E (2009) When will fossil fuel reserves be diminished? Energy Policy 37:181-189. https://doi.org/10.1016/j.enpol.2008.08.016

7. Dincer I (2000) Renewable energy and sustainable development: a crucial review. Renew Sustain Energy Rev 4:157-175. https://doi.org/10.1016/ S1364-0321(99)00011-8
8. VEA (2018) Sustainable development and environmental protection in Vietnam, Vietnam Energy Association. http://nangluongvietnam.vn/ news/vn/bao-ton-nang-luong/phat-trien-nang-luong-ben-vung-va-baove-moi-truong-tai-viet-nam.html. Accessed 24 Mar 2019

9. EVN (2016) Vietnam Electricity Annual Report 2016. In: The Electricity Power Corporation of Vietnam. https://www.evn.com.vn/userfile/files/ 2017/3/AnnualReport2016.pdf. Accessed 10 Aug 2018

10. EVN (2017) Vietnam Electricity Annual Report 2017. In: The Electricity Power Corporation of Vietnam. https://en.evn.com.vn/userfile/User/ huongbtt/files/2018/2/AnnualReport2017.pdf.Accessed 10 Aug 2018

11. EVN (2018) Vietnam Electricity Annual report 2018. In: The Electricity Power Corporation of Vietnam. https://en.evn.com.vn/userfile/User/ huongbtt/files/2019/2/AnnualReport2018.pdf

12. Lerer LB, Scudder T (1999) Health impacts of large dams. Environ Impact Assess Rev 19:113-123. https://doi.org/10.1016/S0195-9255(98)00041-9

13. Tilt B, Braun Y, He D (2009) Social impacts of large dam projects: a comparison of international case studies and implications for best practice. J Environ Manage 90:249-S257. https://doi.org/10.1016/j.jenvman.2008.07. 030

14. Scudder T (2001) The World Commission on dams and the need for a new development paradigm. Int J Water Resour Dev 17:329-341. https:// doi.org/10.1080/07900620120065110

15. Zarfl C, Lumsdon AE, Berlekamp J, Tydecks L, Tockner K (2015) A global boom in hydropower dam construction. Aquat Sci 77(1):161-170. https:// doi.org/10.1007/s00027-014-0377-0

16. Han SS, Vu KT (2008) Land acquisition in transitional Hanoi. Vietnam. Urban Stud 45:1097-1117. https://doi.org/10.1177/0042098008089855

17. Manyari WV, de Carvalho OA (2007) Environmental considerations in energy planning for the Amazon region: downstream effects of dams. Energy Policy 35:6526-6534. https://doi.org/10.1016/J.ENPOL.2007.07. 031

18. Bui TMH, Schreinemachers P (2011) Resettling farm households in Northwestern Vietnam: livelihood change and adaptation. Int J Water Resour Dev 27:1-17. https://doi.org/10.1080/07900627.2011.593116

19. Stickler CM, Coe MT, Costa MH et al (2013) Dependence of hydropower energy generation on forests in the Amazon Basin at local and regional scales. Proc Natl Acad Sci 110:9601-9606. https://doi.org/10.1073/pnas. 1215331110

20. Polo J, Bernardos A, Navarro AA et al (2015) Solar resources and power potential mapping in Vietnam using satellite-derived and GIS-based information. Energy Convers Manag 98:348-358. https://doi.org/10. 1016/j.enconman.2015.04.016

21. EVN (2019) Solar potential in the Central Highlands of Vietnam, The Electricity Power Corporation of Vietnam. https://www.evn.com.vn/c3/ evn-va-khach-hang/Tin-nang-luong-tai-tao-141-17.aspx. Accessed 23 Mar 2019

22. Khuong PM, McKenna R, Fichtner W (2020) A cost-effective and transferable methodology for rooftop PV potential assessment in developing countries. Energies. https://doi.org/10.3390/en13102501

23. Vietnamese MOIT (2017) Vietnam Energy Outlook Report. In: Danish Energy Agency. https://ens.dk/sites/ens.dk/files/Globalcooperation/ Official_docs/Nietnam/vietnam-energy-outlook-report-2017-eng.pdf. Accessed 18 Oct 2018

24. Decision No. $11 / 2017 /$ QD-TTg (2017) On the Support mechanisms for the Development of Solar Power Projects in Vietnam. In: The Vietnamese Prime Minister. http://vanban.chinhphu.vn/portal/page/portal/chinh phu/hethongvanban?class_id $=1 \&$ page $=1 \&$ mode $=$ detail\&document_ $\mathrm{id}=189336$. Accessed 15 Oct 2017

25. Instruction No.1534/BTC-CST (2019) Preferential policy toward under $50 \mathrm{kWp}$ rooftop solar project. In: The Vietnamese Ministry of Finance. https://thuvienphapluat.vn/cong-van/Tai-chinh-nha-nuoc/Cong-van1534-BTC-CST-2019-chinh-sach-uu-dai-doi-voi-du-an-dien-mat-troi-duoi50kw-410737.aspx. Accessed 19 Apr 2019

26. Decision No. 02/2019/QD-TTg (2019) Adjusted and added some terms of the Decision No. 11/2017/QD-TTg of the Government for solar energy development. In: The Vietnamese Prime Minister. http://vanban.chinh phu.vn/portal/page/portal/chinhphu/hethongvanban?class_id=1\& mode=detail\&document_id=195869. Accessed 20 Mar 2019

27. Nguyen NH (2015) Vietnam Power Report 2015. In: The Electricity Power Corporation of Vietnam. www.fpts.com.vn. Accessed 20 May 2017 
28. The Vietnamese Government (2019) Daklak province information. Government office of Daklak, 2019. https://daklak.gov.vn/du-khach. Accessed 15 Apr 2019

29. Statistic office of Daklak (2019) Yearbook statistics of Daklak Province. Statistic publishing, Hanoi

30. Daklak Paper (2019) Rooftop solar electricity: benefit for the investment and electricity industry. http://baodaklak.vn/channel/3483/201905/dienmat-troi-ap-mai-loi-ca-doi-duong-5631364/. Accessed: 20 Jun 2019

31. Fang X, Misra S, Xue G, Yang D (2012) Smart grid - The new and improved power grid: a survey. IEEE Commun Surv Tutorials 14:944-980. https://doi. org/10.1109/SURV.2011.101911.00087

32. Decision No 1670/QĐ-TTg (2012). Approvement of the Smart Grid development project in Vietnam. In: Vietnamese Gov. http://vanban.chinhphu. $\mathrm{vn} /$ portal/page/portal/chinhphu/hethongvanban?class_id=2\&_page= $1 \&$ mode=detail\&document_id $=164399$

33. Okay FY, Ozdemir S (2016) A fog computing based smart grid model. 2016 Int Symp Networks. Comput Commun ISNCC 2016:1-6. https://doi. org/10.1109/ISNCC.2016.7746062

34. Yamane T (1967) Statistics: an introductory analysis 2. Harper and Row, New York

35. Ek K (2005) Public and private attitudes towards 'green' electricity: the case of Swedish wind power. Energy Policy 33:1677-1689. https://doi. org/10.1016/j.enpol.2004.02.005

36. Eagly AH, Chaiken S (2007) The advantages of an inclusive definition of attitude. Soc Cogn 25(5):282-602. https://doi.org/10.1521/soco.2007.25.5. 582

37. Ajzen I (1991) The theory of planned behavior. Organ Behav Hum Decis Process 50:179-211. https://doi.org/10.1016/0749-5978(91)90020-T

38. Roberts JA (1996) Green consumers in the 1990s: profile and implications for advertising. J Bus Res 36(3):217-231

39. Faiers A, Neame C (2006) Consumer attitudes towards domestic solar power systems. Energy Policy 34:1797-1806. https://doi.org/10.1016/j. enpol.2005.01.001
40. Abdullah ZD, Shah T, Jebran K, Ali S, Ali A (2017) Acceptance and willingness to pay for solar home system: survey evidence from northern area of Pakistan. Energy Rep 3:54-60. https://doi.org/10.1016/j.egyr.2017.03.002

41. Chen KK (2014) Assessing the effects of customer innovativeness, environmental value and ecological lifestyles on residential solar power systems install intention. Energy Policy 67:951-961. https://doi.org/10. 1016/j.enpol.2013.12.005

42. Sun PC, Wang HM, Huang HL, Ho CW (2018) Consumer attitude and purchase intention toward rooftop photovoltaic installation: the roles of personal trait, psychological benefit, and government incentives. Energy Environ. https://doi.org/10.1177/0958305X17754278

43. Ahmad S, Tahar BMR, Cheng JK, Yao L (2017) Public acceptance of residential solar photovoltaic technology in Malaysia. PSU Res Rev. 1(3):242-254. https://doi.org/10.1108/PRR-11-2016-0009

44. Nunnally JC (1978) Psychometric theory, 2nd ed. New York, McGraw-Hil

45. Ménard C (1995) Markets as institutions versus organizations as markets? Disentangling some fundamental concepts. J Econ Behav Organ 28(2):161-182

46. Menard S (2001) Applied Logistic Regression Analysis: Sage University Series on Quantitative Applications in the Social Sciences., 2nd ed. Sam Houston State University, USA, University of Colorado

47. Hair JF Jr, Anderson RE, Tatham RL, Black WC (1995) Multivariate data analysis with readings. Prentice Hall International Editions Englewood Cliffs, NJ

48. Hair JF Jr, Black WC, Babin BJ, Anderson RE (1995) Multivariate data analysis, 3rd edn. Macmillan, New York

49. Kennedy JS (1992) The new anthropomorphism. Cambridge University Press

50. Kennedy P (2008) A guide to econometrics, 6th edn. Wiley-Blackwell, Oxford

\section{Publisher's Note}

Springer Nature remains neutral with regard to jurisdictional claims in published maps and institutional affiliations. 